\title{
The Influences of Physical and Chemical Factors to Coral Reef Ecosystem on Coastal Waters Village Eri, Outer Ambon Bay
}

\author{
Wiwien Gaby Hukubun ${ }^{1}$, Nini Munirah Renur², Imanuel Berly Delvis Kapelle ${ }^{3}$ \\ ${ }^{1}$ Fishing Technology Department, Tual State Fisheries of Polytechnic, Southeast Maluku, Indonesia \\ ${ }^{2}$ Fishery Product Technology Department, Tual State Fisheries of Polytechnic, Southeast Maluku, Indonesia \\ ${ }^{3}$ Chemistry Department, Mathematic and Natural Science Faculty, Pattimura University, Maluku, Indonesia \\ Email address: \\ berly_mollucas@yahoo.com (I. B. D. Kapelle)
}

\section{To cite this article:}

Wiwien Gaby Hukubun, Nini Munirah Renur, Imanuel Berly Delvis Kapelle. The Influences of Physical and Chemical Factors to Coral Reef Ecosystem on Coastal Waters Village Eri, Outer Ambon Bay. Journal of Water Resources and Ocean Science. Vol. 5, No. 3, 2016 , pp. 28-36. doi: 10.11648/j.wros.20160503.11

Received: March 3, 2016; Accepted: April 19, 2016; Published: June 13, 2016

\begin{abstract}
This research conducted in coastal waters of Eri, Outer Ambon Bay on July 2011 to analysis the influences of physical-chemical factors of coral reef ecosystem on coastal waters of Eri. Physical-chemical factors of coastal waters measured used CTD. The result measurement data of Current meter and CTD carried out by computer use software equipment. Data processing and graph analyze use the software of Microsoft Excel 2003 and Golden Software Surfer 9. The sample of dissolved oxygen, phosphate and nitrate taken with Nansen Bottle. Dissolved oxygen determined by pursuant to titration Winkler. Rate of phosphate and nitrate analysis by Strikland and Parsons method (1968). The enumeration sample of dissolved oxygen, rate of phosphate and nitrate conducted in laboratory of LIPI Ambon. From research known that the temperature in coast of Eri on July range from $25.9^{\circ} \mathrm{C}-27.3^{\circ} \mathrm{C}$. The salinity ranges from $33.5 \mathrm{ppt}-34.2 \mathrm{ppt}$. The current sea in coastal water of Eri moves follow the current install pattern and withdraw in Ambon Bay. Others influenced by wave which is resulted by monsoon. The turbidity around coast more predominated by inorganic material in the form of refinement sand which suspend effect of current in coast. Phosphate rate detected range from $0.00489-0.0079 \mathrm{ppm}$ and nitrate rate range from $0.0390-0.0671 \mathrm{ppm}$. While gyration assess of dissolve oxygen is lowering with the value $1.99 \mathrm{ppm}$ until $3.38 \mathrm{ppm}$. All of physical and chemical factor was good to influenced coral reef ecosystem on coastal water village Eri.
\end{abstract}

Keywords: Influences, Physic-Chemical, Ecosystem, Coral Reef, Coastal Waters

\section{Introduction}

Coastal water and small islands in Indonesia is commonly surrounding by coral reefs. Growth of good coral reefs located on small island in east Indonesia area was distinguished by clear water environment because less pressure of suspend sediment and excessive freshwater, especially in Maluku, Sulawesi and East Lesser Sundas [1].

Coral reef is an sensitif ecosystem. It even not be destroyed, if we take just one, then become destroyed all of that totality ecosystem. This because life on coral reef based on dependent relationship between thousand of species [2]. It have productivity and biota diversity also high esthetic value, but its very sensitif to environment change. Destroyed of this ecosystem not only can decrease fishery productivity, but also other function from this ecosystem.

Increase of economic value and other needed of society to coral reef resources like fish, lobster, cucumber, etc, will pushed society activity to use its potency pertained big. So ecologic pressure to coral reef ecosystem will be increase too. Increasing of this pressure can threatened existence and performance of coral reef and its biota.

Knowledge of people about coral reef commonly minimum so makes exploitation of coral reef ecosystem more destructive without looking at sustainable principle. Increasing of people on coastal area give serious pressure to coral reef. Low level of knowledge and awareness to 
important function of coral reef, difficult on looking for alternative job increse high and complex pressure to coral reef.

In connection with speed of growth population in coastal area and increase development, especially related to activity not in control in coral reef area and beach, so coral condition become unhealthy and in poor condition. The continuation effect is ecologic and production function from this ecosystem become decrease and lost [3]. Destroyed of coral reef in Indonesia commonly effect by human being activity.

People settlement which center on coastal area of Ambon Island and trend for settlement expansion with reclamation system will influences to coral reef and other sea biota [4]. Other, destroyed of coral reef on some coastal water in Ambon Island caused by less understanding of people about the important of coral reef and their attitude which not care with conservation of coral reef ecosystem. From the information which get about 15-20 years ago, coastal water in Ambon Bay showed nature condition, but increasing of people with a lot of activities in land and waters makes the quality of coral reef ecosystem become fastest decrease [5].

Coastal waters of Eri village located on Leitimur Peninsula Outer Ambon Bay which have the main ecosystem is coral reefs, especially fish coral which high diversity species, and also its potency is pertained big. Go together with the existence of the main ecosystem of coral reefs, hence the government of Maluku Provinces on the plan of coastal area planology, sea and small islands on 2004 had specified coastal area of Eri Village with its coral reefs as local convert area. Others have also been specified in plan settlement of coastal area and sea of Ambon City by the duty Fishery and Oceanic of Moluccas Province (2007) that territorial water of Eri is the tourism maritime area especially for diving and snorkeling [6].

The degradation quality of coral reefs on Eri village by the environmental pressure and the pressure of exploiting nature resources. The impacts descend quality degradation of coral reefs caused ecologic function and production function too. In fact show that coral reefs function as silencer and lessening wave energy become loss because damage of reef, so that coastal eroding become increase and beach wall become destroy. In the other side production function decrease because fish catching become decrease caused of main habitat of fish coral have been destroyed.

Coral reef on Eri Village have 4 zone, that is reef flat zone, reef middle zone, reef margin zone, and reef slope zone. Special for coral reef on Eri Village, Sutarna (1987) found higher coverage of hard coral is $76.40 \%$, while according to Leatemia (1996) coral reef condition become decrease from condition excellent $(76.40 \%$ coverage of hard coral, on 1987) to good condition (42.83\% on 1996). Result from the duty Fishery and Oceanic of Moluccas Province on 2003 showed condition of coral reef in Eri Village coastal waters in good condition with percentage coverage of hard coral is $60.48 \%$. The duty Fishery and Oceanic of Moluccas Province (2007) said that condition of coral reef in this coastal water in poor condition with value of cover percentage of hard coral is $22.63 \%$ [6]. Result of research on reef flat zone on 2009 show that the condition of coral reef in this coastal water has been poor with percent coverage of stony coral is $24.94 \%$ [7].

Decrease of this coral condition will be influenced to organism which stay and live around of coral reef. Based on research which had done before showed that the condition of coral reef on this coastal water has been decrease caused by wave strokes, physic influence and settlement waste. So this research must do to know about the influences of physical-chemical factors to coral reefs on coastal waters of Eri Village. We hope that this research can give information about the influences of physical-chemical factors on coral reefs and its spreading parameters.

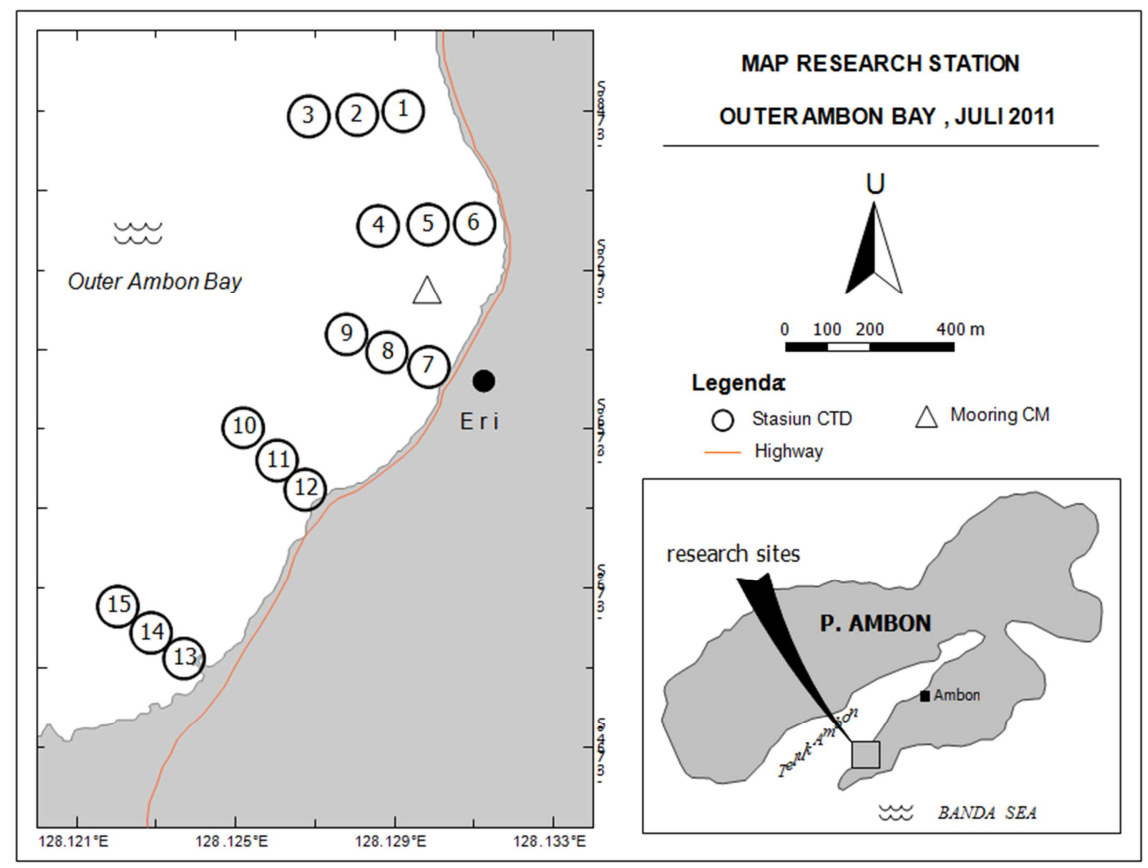

Figure 1. Map of station and research location on coastal waters of Eri. 


\section{Material and Methods}

\subsection{Equipment and Material}

Equipment and material that we used on this research are: speed boat, GPS, Compact-CTD, Current meter, sample bottle, sechi disk, nylon string, aquades, tissue paper, paper and stationery write.

\subsection{Intake Methods and Data Analysis}

Physical-chemical factors that we perceive and measured on the fields use compact-CTD are temperature, salinity and brightness. Data and information was taking with depth variation. After data record appliances on each depth, its result will convert to know the nominal result (digital). The oceanography research was done in coastal waters of Eri, outer Ambon bay on July $1^{\text {st }}-2^{\text {nd }} 2011$, with total station research is 14 consist of 1 clinch current (mooring CTD) and 12 station CTD (figure 1), which determination of coordinate position use GPS type Garmin 76 Cxi.

The current parameter was measured use Current Meter Compact-EM production of Alec Electronics Co., Ltd., Japan. Parameter of temperature, salinity, chlorophil-a and turbidity was measured used Compact-CTD production of Alec Electronics Co., Ltd., Japan. Current measurement was done on surface water of each station to know about current pattern on tidal and withdraw, refer to book of tidal table on 2011, published by Janhidros TNI-AL. Current measuring continue by record deepness on $7 \mathrm{~m}$, near bottom for 4 hours. Result data measurement of current meter and CTD transferred to computer use special software. Data processing and graph also analyze use software of Microsoft excel 2003 and golden software surfer 9 .

Dissolved oxygen sample, phosphate and nitrate taken with

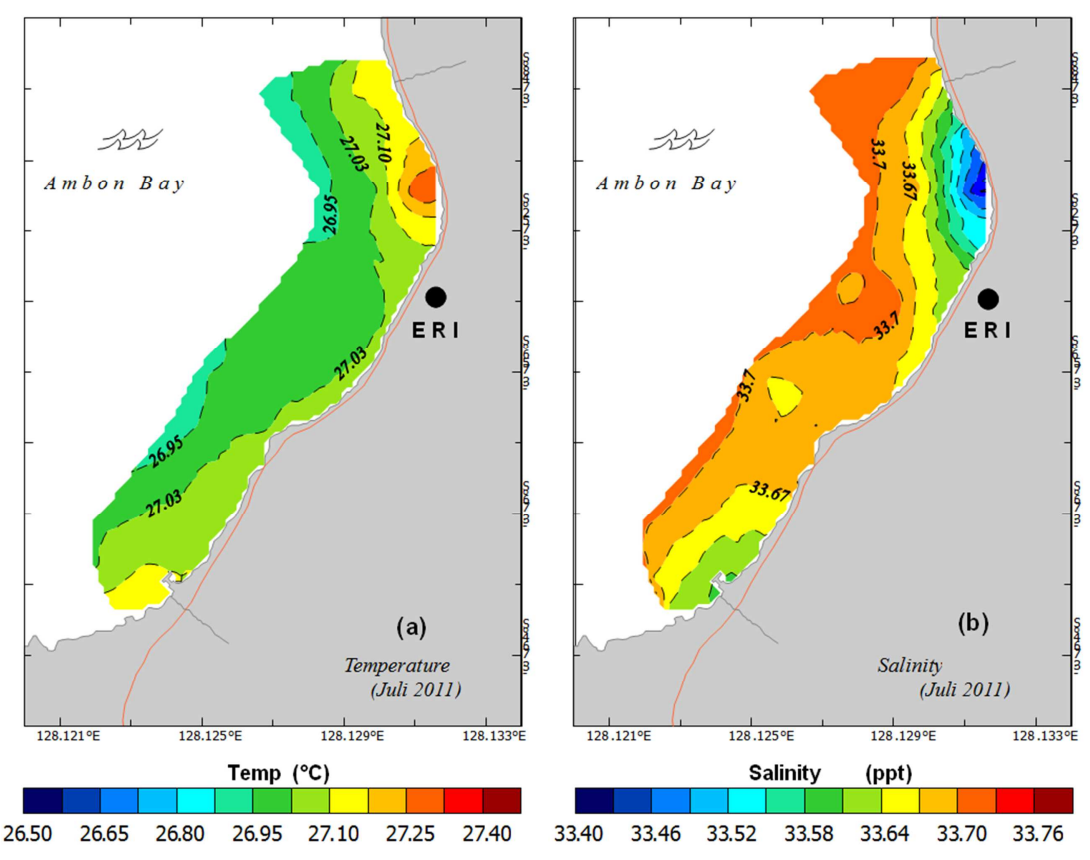

Figure 2. Distribution of temperature and salinity on sea surface.
Nansen bottle in station 8 (transect 3) at deepness is near base (7m). Dissolved oxygen determined by pursuant to titration Winkler, and expressed in ppm (part per million). Rate of phosphate and nitrate analysis [8], both expressed in ppm (part per million). Enumeration sample of dissolved oxygen, phosphate and nitrate conducted in laboratory of LIPI Ambon.

\section{Results and Discussion}

\subsection{Geographical Position}

Eri is a small village of Nusaniwe village located in sub district of Nusaniwe Ambon city, have a distance approximately $12 \mathrm{~km}$ from downtown city of Ambon. Geographically, coastal waters of Eri located in Outer Ambon bay with position $03^{\circ} 45^{\prime} 45,30^{\prime \prime} \mathrm{LS}$ and $128^{\circ} 07^{\prime} 27^{\prime \prime} \mathrm{BT}$ till $03^{\circ} 44^{\prime} 40,98^{\prime \prime}$ LS and $128^{\circ} 07^{\prime} 51,78^{\prime \prime}$ BT (figure 1). Administratively, regional boundary of Eri Village shall be as follows: north side border on Ambon Bay, south side border on Airlouw Village, east side border on Urimessing Village (Amahusu), and west side border Latuhalat Village (Seilale).

\subsection{Temperature and Salinity}

The coastal water temperature of Eri when observation is ranges from $25.9^{\circ} \mathrm{C}-27.3^{\circ} \mathrm{C}$. Horizontal distribution of depth temperature on zero meter at figure $2 \mathrm{a}$, have average value $27.0^{\circ} \mathrm{C}$ and classified same with temperature averages surface coastal waters of Indonesia, with horizontal variation of temperature relative minimize till apart $\sim 200 \mathrm{~m}$ from coastline. Vertical distribution of temperature on figure 3 shows heat stratification on column water, where temperature of sea surface is warmer and decrease by increasing it deepness. 
Decrease of temperature till near base $(25 \mathrm{~m})$ only reach to $26.5^{\circ} \mathrm{C}$ in station $2,5,8,11$ and 14 , while in station $3,4,9,10$ and 15 temperature decrease reach to $25.9^{\circ} \mathrm{C}-26.4^{\circ} \mathrm{C}$ at depth $40-50 \mathrm{~m}$. Maximum temperature change detected in station 4 (transect 2) at depth $33-38 \mathrm{~m}$, with temperature gradient

$0.12^{\circ} \mathrm{C} / \mathrm{m}$. Temperature distribution under this depth reach to $29.5^{\circ} \mathrm{C}$ and temperature above almost homogenous with average value $26,8 \pm 0,05^{\circ} \mathrm{C}$. Water temperature at some depth is presenting in table 1 .
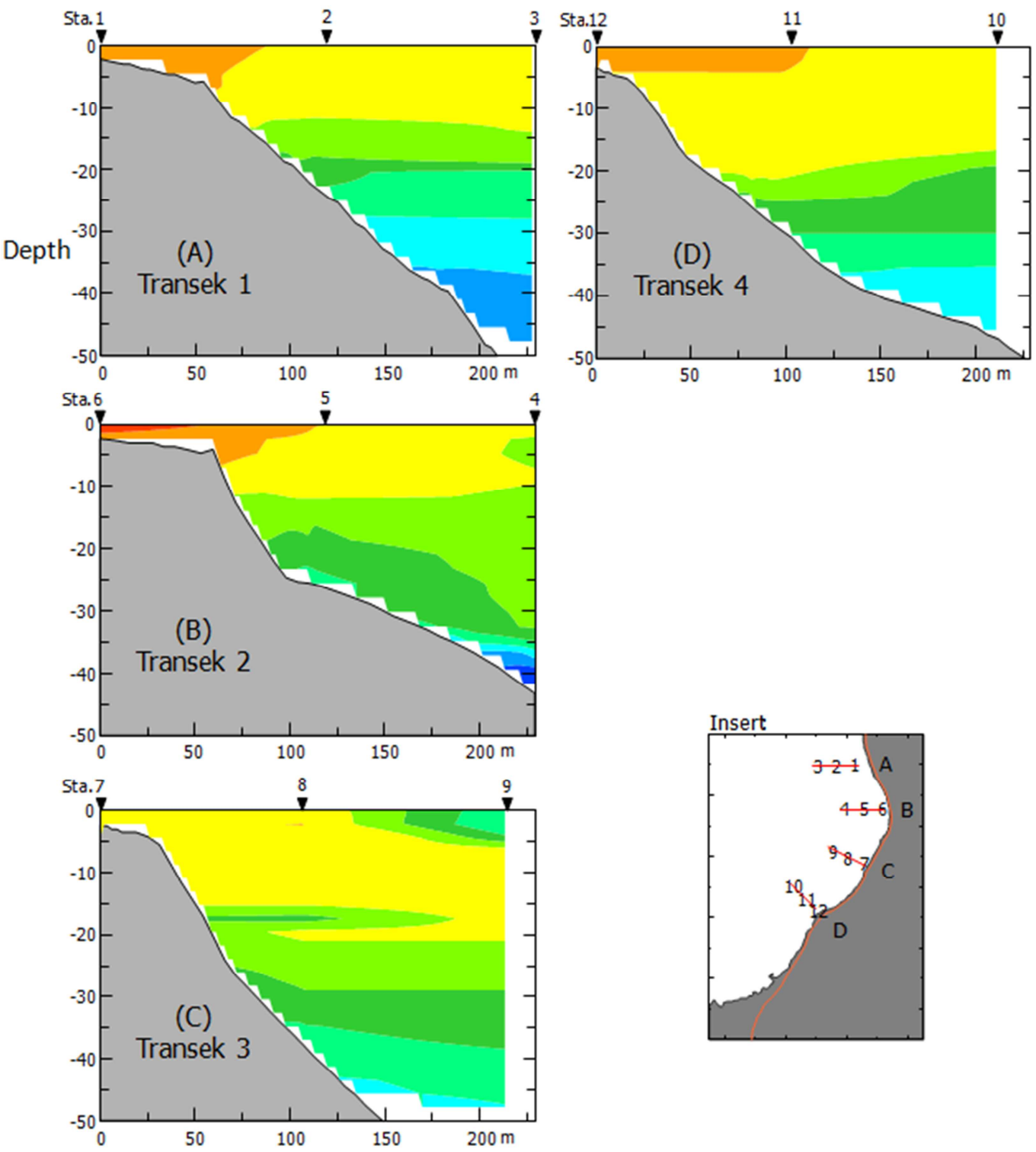

Temp $\left({ }^{\circ} \mathrm{C}\right)$

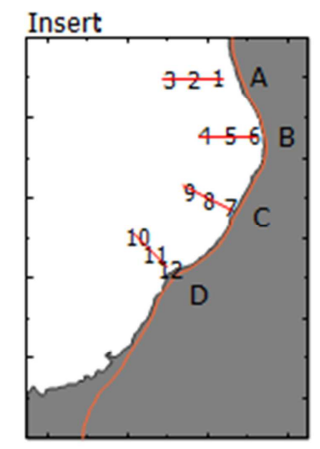

$\begin{array}{llllllllllll}25.8 & 25.95 & 26.1 & 26.25 & 26.4 & 26.55 & 26.7 & 26.85 & 27.0 & 27.15 & 27.3 & 27.45\end{array}$

Figure 3. Vertical distribution of temperature on coastal water of Eri.

Vertical distribution of water temperature in Ambon bay fluctuate follow seasonal temperature change. According to LIPI monitoring data in Ambon Bay on 2008 (May, July and October), average of surface temperature around Amahusu coast and Eri at switchover season I (May) $27.5^{\circ} \mathrm{C}$, and descend become $26.5^{\circ} \mathrm{C}$ at east season (July), then go up till $28.0^{\circ} \mathrm{C}$ at switchover season II (October). Temperature distribution till deepness $40 \mathrm{~m}$ are relative homogenous because of mixing process in bay, with average value $27.2^{\circ} \mathrm{C}$ on May, $26.8^{\circ} \mathrm{C}$ on July and $27.7^{\circ} \mathrm{C}$ on October. Temperature gradient till deepness $40 \mathrm{~m}$ on May is $-0.342^{\circ} \mathrm{C} / \mathrm{m}$, on July $0.405^{\circ} \mathrm{C} / \mathrm{m}$ and on October $-0.567^{\circ} \mathrm{C} / \mathrm{m}$. The unique stratify temperature with positive gradient become on July. This condition shows the heat flow process (heat flux) from sea surface to atmosphere influenced by air temperature at east monsoon. Temperature of coastal waters on research location is pertained to support the growth of stony coral, range from $25^{\circ} \mathrm{C}-28^{\circ} \mathrm{C}$. 

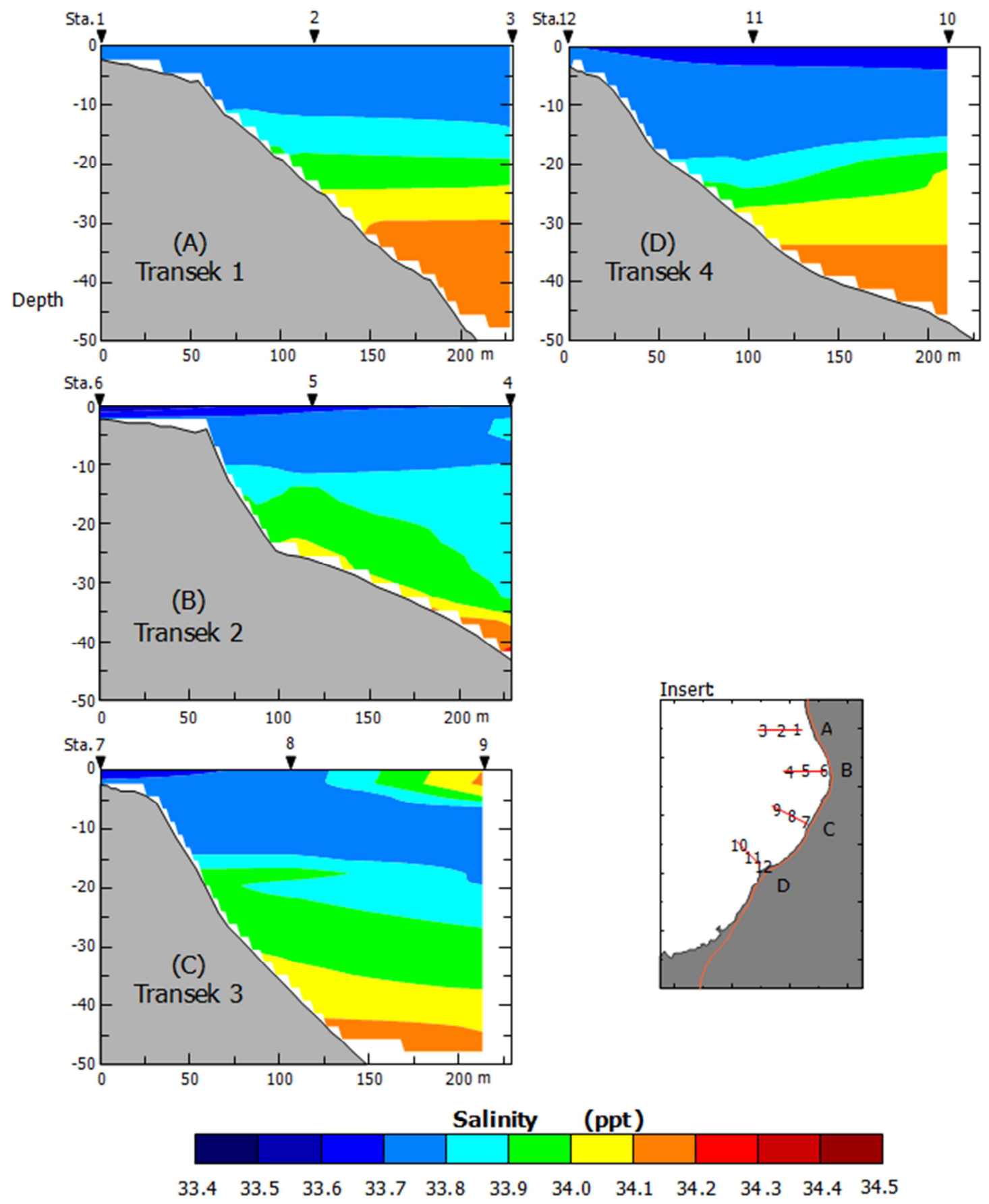

Figure 4. Vertical distribution of salinity in coastal waters of Eri.

Salinity coastal waters of Eri at perception on July 2011 range from $33.5 \mathrm{ppt}-34.2 \mathrm{ppt}$. Low salinity concentration detected on surface with average value $33.7 \mathrm{ppt}$, and horizontal spreading pattern show at figure $2 \mathrm{~b}$. Interaction between coastal waters and open sea, also input of freshwater from continent cause salinity in near coast become low and increase avoid the coast. Low salinity $33.5 \mathrm{ppt}$ had detected in station 6, influenced by freshwater from Waihua river and Waigedung river which nearby transect 1 and transect 2 . Influence of freshwater input from Waiselang river also detected in surface of station 13 (transect 5), with salinity 33.6 ppt. Vertical distribution of salinity in picture 4 show salinity concentrate which increase from base of waters as effect gravity of salt dissolved and water mass circulation in Outer Ambon Bay. The average salinity of some depth in coastal waters of Eri is presented in table 1.

Salinity concentration on other season according to monitoring data of LIPI on 2008, at switchover season I (May 2008) and switchover season II (October 2008) have surface average salinity is $34.0 \mathrm{ppt}$ and $34.3 \mathrm{ppt}$, higher than east season (July 2008) with salinity is 33.5 ppt. The difference salinity concentration effect by rainfall seasons in downtown of Ambon usually increase at east season (June - August). 
Table 1. The Average Value of Temperature, Salinity, Turbidity and Chlorophil-a in some Depth on July $1^{\text {st }} 2011$.

\begin{tabular}{lllllll}
\hline \multirow{2}{*}{ Parameter } & Depth & & & & & \multirow{2}{*}{ Unit } \\
\cline { 2 - 6 } & $\mathbf{0 ~ m}$ & $\mathbf{5 ~ m}$ & $\mathbf{1 0 ~} \mathbf{~ m}$ & $\mathbf{1 5 ~} \mathbf{~ m}$ & $\mathbf{2 0 ~} \mathbf{~}$ & \\
\hline Temperature & 27.02 & 26.96 & 26.92 & 26.85 & 26.66 & ${ }^{\circ} \mathrm{C}$ \\
Salinity & 33.67 & 33.74 & 33.77 & 33.83 & 33.95 & $\mathrm{Ppt}$ \\
Turbidity & 0.44 & 0.38 & 0.35 & 0.33 & 0.36 & $\mathrm{Ftu}$ \\
Chlorophil-a & 0.60 & 0.57 & 0.56 & 0.51 & 0.40 & $\mathrm{Ppb}$ \\
\hline
\end{tabular}

\subsection{Current Circulation}

Current circulation in coastal waters of Eri is moved follow the pattern of tidal current and withdraw current in Ambon Bay, which current moved into from north till northeast on tidal and withdraw move out to south and southwest. Current speed based on result of perception in coast of Eri at July $1^{\text {st }}$ 2011 (east season) presented in table 1. Surface current pattern of tide and withdraw in figure 5 and result of mooring current in figure 6 and 7, showing current movement around the coast (long shore current) following the coastline with average speed of tide current $17.7 \mathrm{~cm} / \mathrm{second}$ in surface, and near base it became weak till $12.1 \mathrm{~cm} / \mathrm{sec}$ at depth $7 \mathrm{~m}$. Low tide current flow on the surface with average speed $16.2 \mathrm{~cm} / \mathrm{sec}$ and become weak near base with speed $8.6 \mathrm{~cm} / \mathrm{sec}$. Current speed in Ambon Bay when low tide on zero meter depth average $11.48 \mathrm{~cm} / \mathrm{sec}$, in depth $15 \mathrm{~m}$ average $9.97 \mathrm{~cm} / \mathrm{sec}$, and high tide in zero meter depth average $11.35 \mathrm{~cm} / \mathrm{sec}$, and in depth 15 $\mathrm{m}$ average $6.97 \mathrm{~cm} / \mathrm{sec}$ [9]. The speed difference of tide current in surface and near base, the strong current tide will be found in surface and will decrease near base, caused by bottom friction.

The power of current in coastal water of Eri influenced by tide condition, also wave which rise on by the monsoon wind. The wind blow on east season in coast Eri (June - August) usually weak because of obscure by land and hill, while on west season (December - February) wind usually increase with strong wave. Average high wave in Outer Ambon Bay on east season reach to 0.515 meter [10].

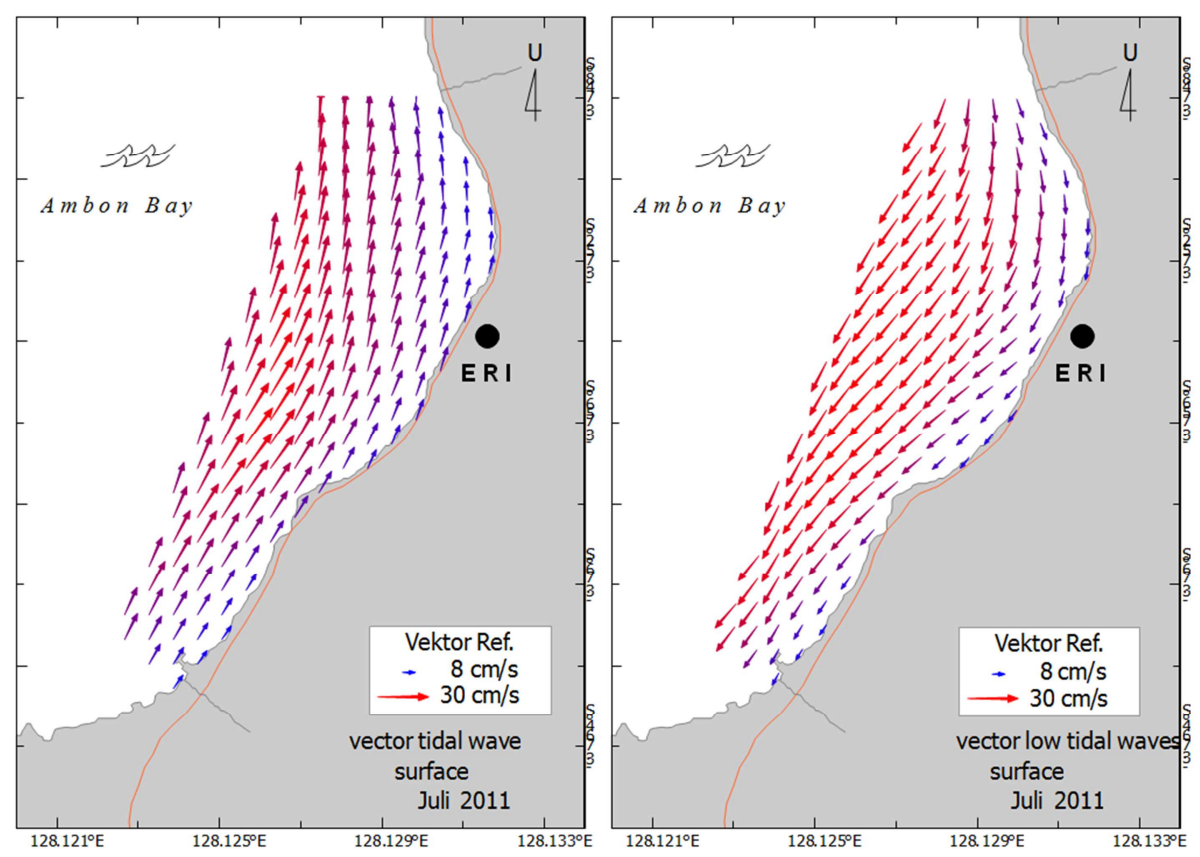

Figure 5. The current pattern of low tide and high tide on tide average (MSL).

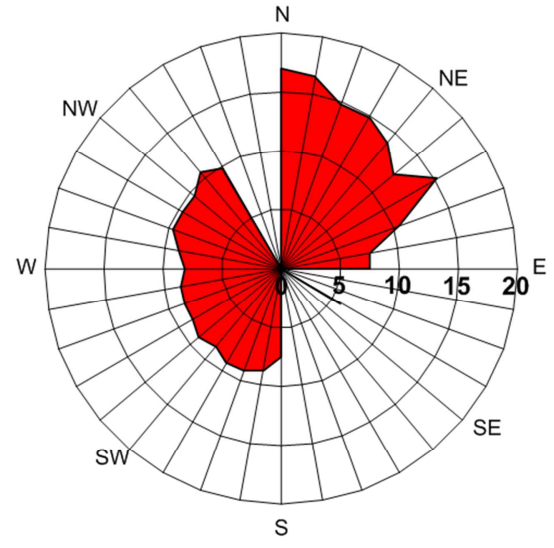

(a)

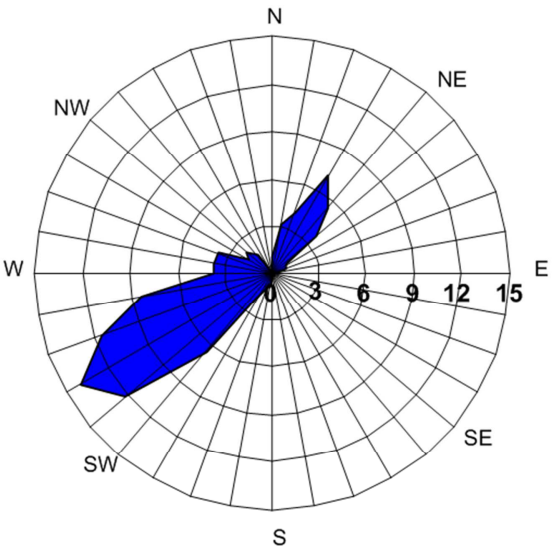

(b)

Figure 6. Rose diagram of current in depth $7 \mathrm{~m}$; (a) speed to direction (cm/det), and (b) frequency of direction (\%). 
Wave at west season have incidence angle almost vertical to coastal $\left(\sim 90^{\circ}\right)$, and different of hydrostatic pressure cause long shore current which potency to destroy wave breaker construction along Eri coast caused by erosion and sediment transport. Base sediment of Outer Ambon Bay dominated by sand fraction. Sediment transport direction along the coast of Outer Ambon Bay cannot be determined (no certain direction) [11].

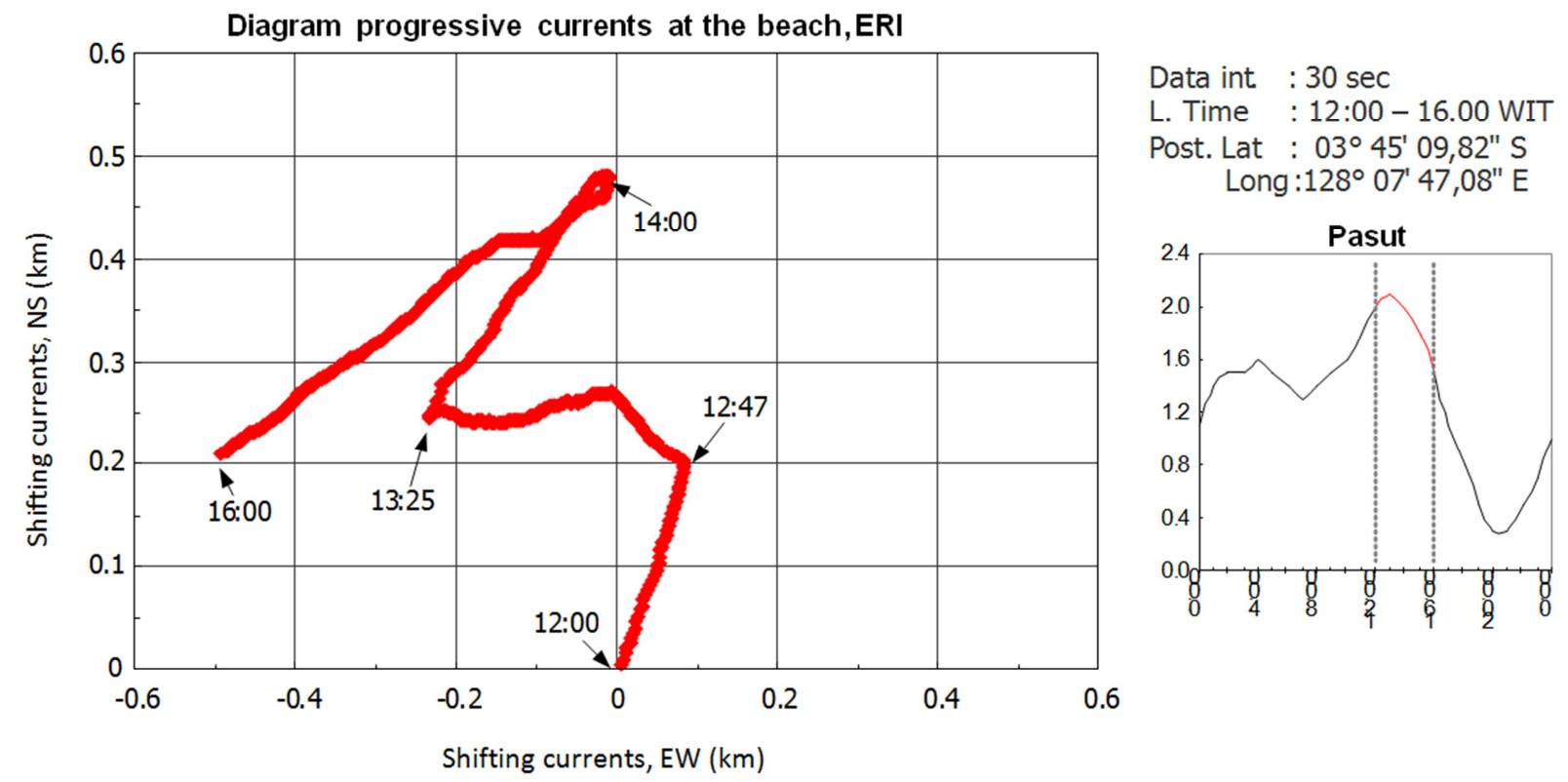

Figure 7. Current friction diagram on depth $5 \mathrm{~m}$ di coastal waters of Eri.

\subsection{Waters Turbidity and Brightness}

Turbidity which detected use CTD ranges from 0.240 0.970 NTU. Turbidity distribution on waters column in station $1,6,7,12$ and 13 which near with coast is commonly higher, higher value $0.970 \mathrm{NTU}$ in station 7 (transect 3). The station which far from coast (middle and outside), turbidity average less than 0.4 NTU till $20 \mathrm{~m}$ depth (figure 8). Withdraw current movement influenced to smooth sand material suspension in station 7 , brought from transect 1 and 2 have sand reef flat till $117 \mathrm{~m}$ to sea.

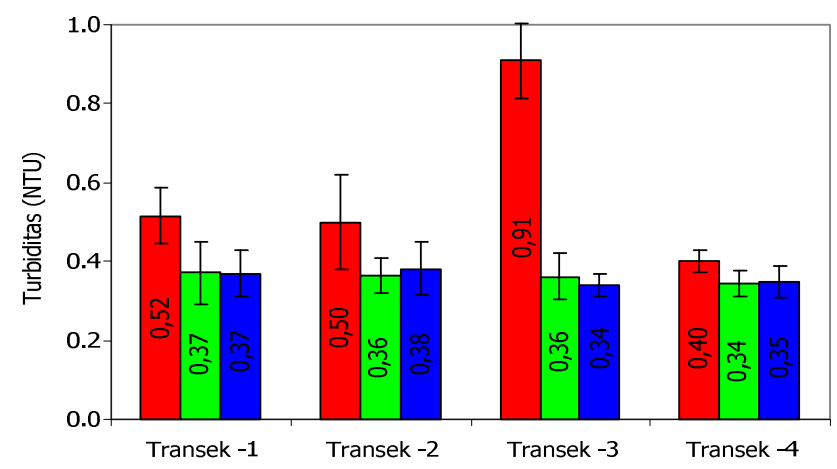

Figure 8. Turbidity average value till $20 \mathrm{~m}$ depth

Waters turbidity caused the waters become turbid and can prevent sunlight penetration to water column. Turbidity vertical distribution on coastal waters of Eri present in figure 9. Turbidity around coast (station 1, 6, 7, 12 and 13) more predominated by inorganic material like smooth sand which suspend caused by current in the coast. Low turbidity on station which far from the coast, predominated by organic material in the form of plankton which flew out in water column follow the current. Minimum water brightness depth in this observation at station 8 and maximum depth $35 \mathrm{~m}$ in station 4.

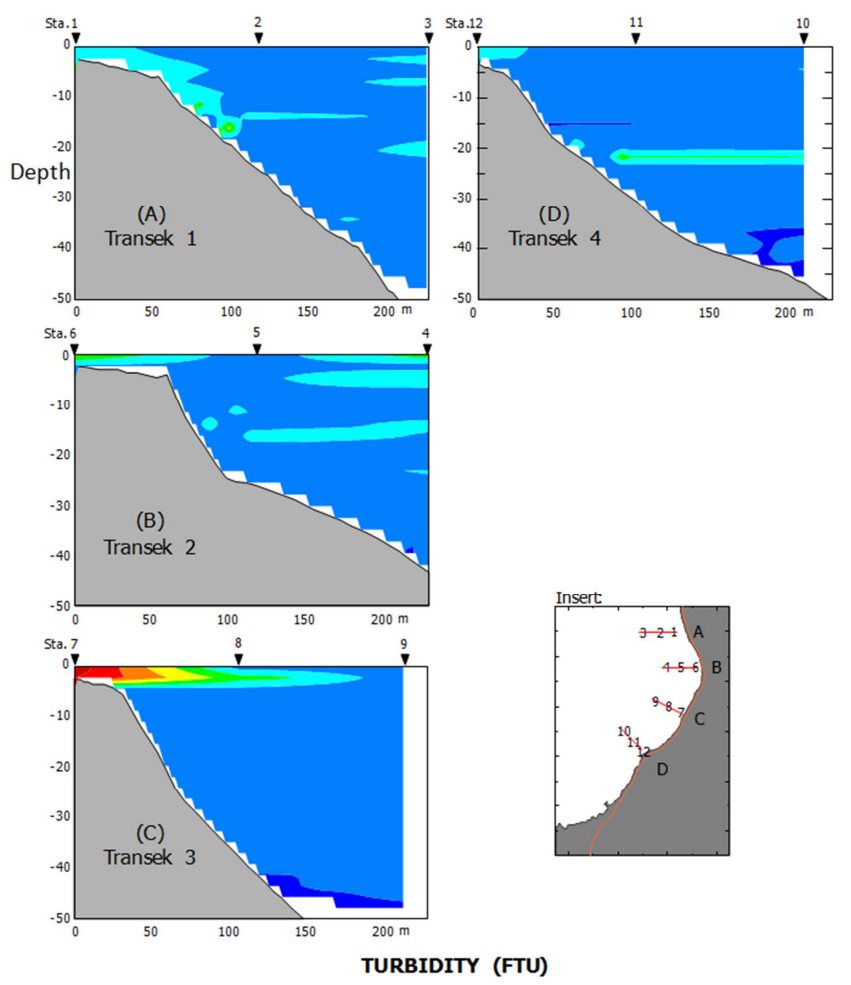

Figure 9. Turbidity vertical distribution on coastal waters of Eri. 


\subsection{Contents of Nitrate, Phosphate and Dissolved Oxygen}

Dirty removal usually contained a lot of nitrate and phosphate. Both was as nutrition for plants, so increasing phytoplankton in waters, also benefit for zooplankton and multiply other food chain. Domestic waste which disentangled by bacteria, not only carbon dioxide $\left(\mathrm{CO}_{2}\right)$ and water $\left(\mathrm{H}_{2} \mathrm{O}\right)$, but also nitrogen and phosphorus release as anorganic matter, which naturally contained in protein component of plant and animals. Nitrate, phosphate and other salts was as important nutrition to plant growth, without nutrition there is no plant growth. However, if a lot of water step into water body, not yet good for water ecosystem [12]. Abundant of nutrition in waters exactly make new problem, that is blooming microorganism population which impact to dissolved oxygen supply.

Nitrate is a nutrient needed by organism, included in sea. In the sea, nitrate required by diatoms which as the main component flora on the sea. Like most algae, this types besides need phosphate and silicate, also need nitrate for its life growth and development. Phosphate rate detected on depth near base $(7 \mathrm{~m})$ range from $0.00489-0.0079 \mathrm{ppm}$ and nitrate rate range from $0.0390-0.0671 \mathrm{ppm}$. Increase of nitrate concentration by added its depth, and phosphate too. Figure 8 showed that content of nitrate, nitrite and phosphorus is become bigger more and more to the sea. Nutrients rate on waters column base present in picture 9, showed nutrients above reef (station 9) is higher and progressively onshore (station 7) on the wane. Nutrient distribution is more coming from reef on inclination till $12 \mathrm{~m}$ depth. Nutrient source from land which step into this territorial waters come from Waihua river, Waigedung river and Waiselang river is estimate very small.

In general, rate of nitrate and phosphate in Ambon Bay become higher on east season than on west season. Inner Ambon Bay inclined to have higher rate of nitrate and phosphate than in Outer Ambon Bay. Its caused of the area of Inner Ambon Bay is smaller than Outer Ambon Bay which bigger and wide also related to Banda Sea, so that continent influenced is more stick out on Inner Ambon Bay [10].

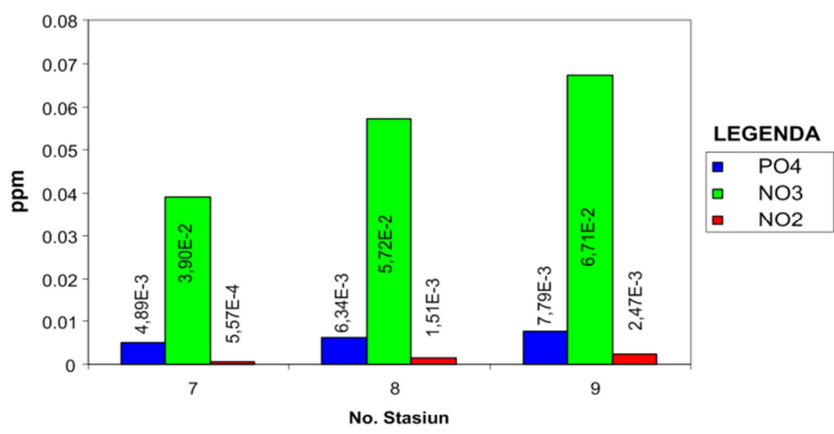

Figure 10. Nutrients rate; phosphate, nitrate and nitrite on coastal waters of Eri.

Dissolved oxygen is important parameter required by all water organism, like fish. No oxygen in the water is very dangerous for aquatic life. A lot of fish was died in some waters was not caused directly by toksisitas of wastes, but caused by less oxygen waters was used in decomposition process by microorganism [12]. Oxygen which contained in the sea came from the air by diffusion process and result of photosynthesis. Because most of dissolved oxygen on the water is come from the air, so compared of oxygen rate in surface layer is higher than under it. Oxygen condensation in the water depends on water temperature. If temperature of sea is high more and more, hence more and more to lower oxygen condensation [11]. Progressively in sea, hence progressively less light intensity which can reach it, it means oxygen production become more lower by zooxanthellae of stony corals.

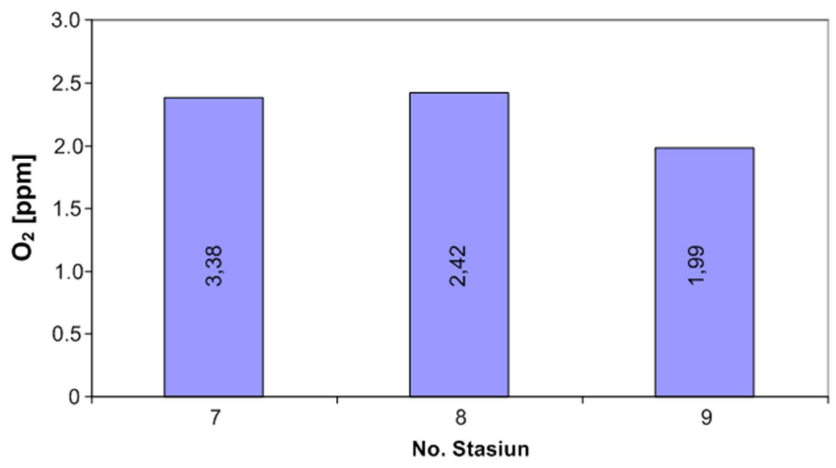

Figure 11. Dissolved oxygen rate in coastal water of Eri.

According to statement above, hence temperature at research location is range from $26.66^{\circ} \mathrm{C}$ till $27.02^{\circ} \mathrm{C}$ and value gyration of dissolved oxygen is lower with the value is 1.99 ppm till $3.38 \mathrm{ppm}$. Content of dissolved oxygen on coastal water of Eri is presented in picture 11.

\section{Conclusion}

Temperature on research location pertained to support good growth of stony corals that is range from $25.9^{\circ} \mathrm{C}-27.3^{\circ} \mathrm{C}$. Salinity coastal waters of Eri range from $33.5 \mathrm{ppt}-34.2 \mathrm{ppt}$. Current on coastal water of Eri move follow the pattern of tide current and withdraw in Ambon Bay. Others influenced by wave caused of season wind. Turbidity around of coast predominated by inorganic material like smooth sand suspension caused by current of coast. Phosphate rate detected range from $0.00489-0.0079 \mathrm{ppm}$ and nitrate rate range from $0.0390-0.0671 \mathrm{ppm}$. While gyration value of dissolved oxygen is low with the value $1.99 \mathrm{ppm}$ till $3.38 \mathrm{ppm}$. All of physical and chemical factor was good to influenced coral reef ecosystem on coastal water village Eri.

\section{References}

[1] Alkatiri, S. Y. 2007. Study Condition of Coral Reef in Coastal Water of Some Small Island in Subdistrict Gorom Island, East Seram Regency. Minithesis. Fishery and Marine Science Faculty, Pattimura University, Ambon.

[2] Ambon Express. $3^{\text {rd }}$ November 2007. Know Coral Reef Ecosystem. 11 pp. 
[3] Sahetapy, D. 2010. Coral Reef Existence on Coastal Water Ambon Bay. TRITON, Journal of Waters Resources Management, Fishery and Marine Science Faculty, Pattimura University.

[4] Fattaroeba, I. 2001. Condition of Coral Reef and Conservation Effort in Coastal Beach Hitu Village Leihitu Subdistrict Ambon Island. Scholarly paper. Fishery and Marine Science Faculty, Pattimura University, Ambon: 1-7.

[5] Sahetapy, L. 2000. Reef Status and Community Structure of Coral in Coastal Water of Seilale, Outer Ambon Bay. Minithesis. Fishery and Marine Science Faculty, Pattimura University, Ambon. 8-24.

[6] Duty Fishery and Oceanic of Maluku Province. 2007. Coral Reef Rehabilitation on Coastal Waters Village Eri, Ambon City. Duty Fishery and Oceanic Of Maluku Province: 40p.

[7] Hukubun, W. G. 2009. Reef status and Community Structure of
Coral on Reef Flat Zone on Coastal Water Village Eri, Outer Ambon Bay. Minithesis. Fishery and Marine Science Faculty, Pattimura University, Ambon.

[8] Strickland JDH, Parsons TR. 1986. A Practical Handbook of Sea Water Analysis. Fish. Res. Board. Canada 16 (7): 311 p.

[9] Hamzah MS, Wenno LF. 1987. In the Gulf Stream circulation Ambon. Marine Resources Research and Development Agency, Puslitbang Oceanology-LIPI Ambon. 91-101.

[10] Tarigan, Z. 1987. The content of nitrates in Ambon Bay. Marine Resources Research and Development Agency, Puslitbang Oceanology-LIPI Ambon. 102-105.

[11] Hutagalung HP, Rozak A, Lutan I. 1985. Oseana, 10 (4): 138 149. Indonesian Institute of Sciences. National Oceanology institute. Jakarta.

[12] Selanno, D. A. J. 2011. Load Pollution on Bay Ecosystem: Perspective Management Environment Quality. 